\title{
IMPRESSION OF NATCOM OIL AND ADHATODA VASICA NEES \\ EXTRACTS ON HATCHABILITY OF SPODOPTERA LITTORALIS (BOISD) EGGS UNDER LABORATORY CONDITIONS
}

\author{
AMANY S. EL-HEFNY, H.A. SALEH. AND SH.S. YACOUB
}

Plant Protection Research Institute, ARC, Dokki, Giza

(Manuscript received 7 July 2008)

\begin{abstract}
The effects of Natcom oil ( $40 \%$ Jojoba oil $+59 \%$ mineral oil $1 \%$ garlic oil) and Adhatoda vasica leaves (water, ethanol, hexane and acetone) extracts were evaluated on hatchability of Spodoptera littoralis eggs at different ages ( $1 \& 5$ days) under laboratory conditions $27 \pm 2{ }^{\circ} \mathrm{C}$ and $70 \pm 5 \mathrm{RH}$.

It was found that Natcom 40 at the different tested concentration had the highest effect against all the tested ages of egg, unless the lowest concentration $1 \%$ had the best effect of all, causing $94 \%$ and $87.4 \%$ reduction for 1 and 5 days old of eggs, respectively.

Adahatoda vasica leaves water and ethanol extracts showed also high effect on eggs compared with the remaining solvents (Acetone and Hexane).

Generally, Preparation of plant extracts were relatively more effective against eggs 5 day old than the ones of 1 day old.
\end{abstract}

\section{INTRODUCTION}

The cotton leafworm, Spotoptera littoralis (Lep., Noctuidae), is a major pest of cotton and on other cultivated crops in Egypt, (Ahmad, 1988).

Plants are rich sources of natural substances that could be utilized in the development of environmentally safe materials for pest control. The deleterious effects of certain purified phytochemical or crude plant extracts on insects are manifested in several ways, including toxicity (Hiremath et. al., 1997)

Adhatoda vasica Nees (Acanthaceae) plant, is mainly cultivated for pharmaceutical purposes, also its leaves were highly effective against $S$. littoralis (Antonious et al., 1992).

The efficacy of jojoba oil clearly decreases the number of eggs of Tetranychus arabicus, (El-Duweini and Sedrak, 1997).

The aim of this work is to evaluate Natcom oil $40, A$. vasica leaves and a mixture of $1 \%$ Natcom oil plus $2 \%$ water extract of $A$. vasica leaves on the percentage of hatchability of $S$ littoralis eggs of different ages. 


\section{MATERIALS AND METHODS}

\section{I . Material preparation:}

$A$. vasica leaves were washed by water and then dried in shade under laboratory conditions then ground in a high speed grinder. Extraction in the laboratory by different organic solvents of increasing polarities, water, ethanol, Acetone and hexane at ratio of I (gm powder) : 2 ( $\mathrm{cm}^{3}$ solvent) in blender for 15 minutes then filtered (Afifi et al., 1988).

A volume of 50 and $100 \mathrm{~cm}^{3}$ of water was added to the former crude extracts to obtain an emulsion of the desired extracts at two concentrations. Also, extracts in boiling water as described by Emara et al., (1994), then powder of extracts was dissolved / $100 \mathrm{ml}$ water and stirred for 10 minutes then filtered to obtain suspension at 2, 4 and $8 \% \mathrm{~W} / \mathrm{V}$.

Natcom 40 formulation ( $40 \%$ Jojoba oil $+59 \%$ mineral oil $+1 \%$ garlic oil) was prepared by adding 1,2 and $4 \mathrm{ml} / 100$ water being 1, 2 and $4 \% \mathrm{~W} / \mathrm{V}$ concentrations. Also, a mixture of $1 \%$ Natcom oil $40 \%$ plus $2 \%$ water extract of $A$. vasica leaves were evaluated on eggs of different ages.

\section{Laboratory bioassay}

Two different ages of $S$. littoralis, egg-masses, newly laid ( 1 day and 5 days, old) were used. Each age was divided to three replicates, then sprayed with the different concentrations of the forementioned materials. All egg-masses were left in the laboratory to dry using electric van. Then the egg-masses were kept in glass tube until hatching at $27 \pm 2{ }^{\circ} \mathrm{C}, 70 \pm 5 \% \mathrm{RH}$. Percentage of hatchability was calculated by the following formula:

$\%$ hatchability $=$ number of hatched eggs $\quad X 100$ total number of eggs in cluster

$\%$ reduction $=\underline{\text { No. egg hatchability in check }- \text { No. egg hatchability in treatment }} \times 100$

No. egg hatchability in check

according to Reda (2007).

\section{Statistics:}

Results were analyzed using two ways, ANOVA and mean separate which was conducted using L.S.D. ( $P>0.01)$ using $M$ stat program.

\section{RESULTS AND DISCUSSION}

\section{A-On eggs one day old}

As shown in Table (1), the mixture of $1 \%$ Natcom oil $40 \%$ plus $2 \%$ water extract caused the highest toxicity on $S$. littoralis eggs on 1 day old causing $5.4 \%$ hatchability 
as $94.4 \%$ reduction than control $(95.8 \%$ hatchability) and had a high significant reduction than the remaining treatments.

In the same Table (1) data obviously showed that Natcom oil $40 \%$ oil came the second in efficacy after the mixture, either with concentration 1 or $4 \%$ causing 12.1 and $14.5 \%$ hatchability as 87.4 and $84.9 \%$ reduction, respectively. While Natcom oil $40 \%$ in $2 \%$ concentration caused $81.6 \%$ reduction than control.

While, $A$. vasica water extract at 8,4 and $2 \%$ concentration and ethanol at $1.6 \%$ caused the inter-mediate effect and could be arranged in descendingly order according to percentage of hatchability and reduction than control as follows: (16.1\% hatchability, $83.2 \%$ reduction), (23.7, 75.3\%), (28.7, 70\%) and (29.6, 69.1\%), respectively.

While, $A$. vasica acetone extract ranked the pre last level with concentration 0.8 and $0.4 \%$ achieving $54.9 \%$ and $60 \%$ hatchability.

Lastly, $A$. vasica hexane extract had a significant reduction with the fomer treatments having the lowest effect on the percentage of hatchability, being 87.9 and $89.1 \%$ resulted from the concentrations 0.8 and $0.4 \%$, respectively.

\section{B-On eggs five days old}

Data in Table (2), clearly showed that all the tested extracts and preparations achieved similar results to that obtained on eggs one day old. .In which the highest efficacy of extracts on hatchability was for Natcom oil 40\% EC at 1 and $4 \%$ concentration achieving 5.6 and $5.9 \%$ hatchability, respectively, as $94 \%$ reduction than control for both concentration.

While the mixture ranked the third level in efficacy against $S$. littoralis eggs, causing 8.6 and $90.7 \%$ reduction than control.

The remaining tested extracts could be classified to have an intermediate effect on hatchability including water $A$. vasica extract at 8 and $4 \%$ concentration, ethanol $A$. vasica extract at $1.6 \%$, water $A$. vasica extract at $2 \%$ and ethanol $A$. vasica extract at $0.8 \%$, respectively, achieving ( $16.1 \%$ hatchability, $87.9 \%$ reduction than control), $(13.3 \%, 85.8 \%),(22.4 \%, 76 \%)$ and $(22.4 \%$ and $76 \%)$, respectively. Followed by acetone $A$. vasica extract at 0.8 and $4 \%$ concentration (50.7\% hatchability, $45.7 \%$ reduction) and (55.7\% hatchability, $40.4 \%$ reduction), these reductions were significantly with the next treatment.

Lastly, the least effect on the percentage hatchability obtained from hexane $A$. vasica extract 0.8 and $0.4 \%$ having insignificant reduction, 85.4 and $88.3 \%$ hatchability opposite to $90.7 \%$ for the control.

These results may be strikingly the efficacy of solvents having high polarity as water and ethanol in which they are responsible for extracting the active ingredient. Also, the pervious results are in agreement with that obtained by Sadek (2003) who illustrated that the extracts of $A$. vasica had a toxic activity against $S$. littoralis larvae and Yacoub (2006) clearly demonstrated that the lowest percentage of hatchability of 
eggs recorded from Natcom and methanol $A$. vasica extract against Sesamia cretica egg-masses. Also, the results are in harmouny with Abdel Monem et al (1995) in which they stated that the impression of plant extracts on hatchability of $S$. littoralis eggs (3days old) was more than on newly laid ones.

Table 1. Effect of Natcom oil and Adhatoda vasica leaf extracts $1-5$ day old eggs of Spodoptera littoralis under laboratory conditions.

\begin{tabular}{|c|c|c|c|c|}
\hline Extracts & Solvents & Conc. $\%$ & Hatchability & $\%$ Reduction \\
\hline \multirow{3}{*}{ A. vasica } & \multirow{3}{*}{ water } & 2 & $28.7 a b$ & 70 \\
\hline & & 4 & 23.7ab & 75.3 \\
\hline & & 8 & $16.1 \mathrm{a}$ & 83.2 \\
\hline \multirow{6}{*}{ A. vasica } & \multirow{2}{*}{ Ethanol } & 1.6 & $29.6 a b$ & 69.1 \\
\hline & & 0.8 & $30.4 b$ & 68.3 \\
\hline & \multirow{2}{*}{ Acetone } & 0.8 & $54.9 c$ & 42.7 \\
\hline & & 0.4 & $60 c$ & 37.4 \\
\hline & \multirow{2}{*}{ Hexane } & 0.8 & $87.9 d$ & 8.2 \\
\hline & & 0.4 & $89.1 \mathrm{~d}$ & 7 \\
\hline \multirow{3}{*}{ Natcom } & & 1 & $12.1 \mathrm{a}$ & 87.4 \\
\hline & & 2 & $17.6 \mathrm{a}$ & 81.6 \\
\hline & & 4 & $14.5 \mathrm{a}$ & 84.9 \\
\hline The mixture & & $1: 2$ & $5.4 a$ & 94.4 \\
\hline Control & - & - & $95.8 d$ & \\
\hline F value & \multicolumn{4}{|c|}{47.98} \\
\hline LSD & & & 17.34 & \\
\hline
\end{tabular}

Table 2. Effect of Natcom oil and Adhatoda vasica leaf extracts on 5 days old eggs of Spodoptera. littoralis under laboratory conditions.

\begin{tabular}{|c|c|c|c|c|}
\hline Extracts & Solvents & & Hatchability & $\%$ Reduction \\
\hline \multirow{3}{*}{ A. vasica } & \multirow{3}{*}{ water } & 2 & $24.4 a b$ & 73.9 \\
\hline & & 4 & $13.3 a$ & 85.8 \\
\hline & & 8 & $11.3 a$ & 87.9 \\
\hline \multirow{6}{*}{ A. vasica } & \multirow{2}{*}{ Ethanol } & 1.6 & $22.4 a b$ & 76 \\
\hline & & 0.8 & $32.6 b$ & 65.1 \\
\hline & \multirow{2}{*}{ Acetone } & 0.8 & $50.7 \mathrm{c}$ & 45.7 \\
\hline & & 0.4 & $55.7 c$ & 40.4 \\
\hline & \multirow{2}{*}{ Hexane } & 0.8 & $85.4 d$ & 8.7 \\
\hline & & 0.4 & $88.3 \mathrm{~d}$ & 5.5 \\
\hline \multirow{3}{*}{ Natcom } & & 1 & $5.6 a$ & 94 \\
\hline & & 2 & $9.5 a$ & 89.8 \\
\hline & & 4 & $5.9 a$ & 94 \\
\hline Mixture preparation & & $00: 00$ & $8.6 a$ & 90.7 \\
\hline Control & & & $93.4 d$ & \\
\hline F value & & & 34.98 & \\
\hline LSD & & & 19.77 & \\
\hline
\end{tabular}




\section{REFERENCES}

1. Abdel-Monem, Eglal, M. G.A. Khadr, M.F. El-Mitwally and M.A. Taha. 1995. Effect of six plant extracts on hatchability of Ostrinia nubilalis (Hubn.) and Spodoptera littoralis (Boisd.) eggs in the laboratory J. Appl. Sci 10(3): 304 - 312.

2. Afifi, F.A., A.M. Hekal and M. Salem. 1988. Fenugreek seed extrct as protectants of wheat grain certain strored product insects. Annals of Agric. Sc., Fac. Agric., Ain Shams Univ., Cairo, Egypt, 33(2): 1331 - 1344.

3. Ahmad, T.R. 1988. Field studies on pheromone trapping of cotton leafworm Spodoptera littoralis (Boisd.) (Lep., Noctuidae). J. Appl. Ent. 105, 212 - 215.

4. Antonious, A.G., G. Aegayy, M.F. Shoarawy, L.A. Youssef. 1992. Reaction of the cotton leafworm Spodoptera littoralis (Boisd.), feeding on certain plant leaves: 3. Latent effect of larval feeding mededelingen van de Faculteit landbouwwetenschappen univesiteit Gent 57: 707 - 713.

5. El-Duweini, F.K. and R.A. Sedrak. 1997. Evaluation of Jojoba oiul for control of spider mite (Acari: Tetranychidae) in Egypt. Proc. Beltwide cotton Conf. New Orleans, LA: 1060 - 1063.

6. Emara, M.M., A.G. El-Sisi and S.A. Mahmoud. 1994. Formulation and evaluation of certain local natural products against Varroa, a mite infesting bee colonies. J. Agric. Sci. Mansoura Univ., 19(5): $1843-1850$.

7. Hiremath, I.G., Y.J. Ahn, S.I. Kim. 1997. Insecticidal activity of Indian plant extracts against Nlaparvata lugens (Homoptera: Delphacidae) Appl. Entomol. Zool. 32: $159-166$.

8. Reda, A.M.M. 2007. Effect of certain Bio-insecticides and gama irridation on some biological aspects of the pink bollworm. J. of Agric. Res., Egypt. 85(4): 1285 1301.

9. Sadek, M.M. 2003. Antifeedant and toxic activity of Adhatoda vasica leaf extract against Spodoptera littoralis (Lep.: Noctuidae). J. Appl. Ent. 127: 369 - 404.

10.Yacoub, Sh. S. 2006. Efficacy of some plant extracts in controlling Sesamia cretica Led. and Ostrinia nubilalis (Hubn.) in maize fields. Ph. D Thesis, Fac of Agric., Benha University, Egypt. 


\title{
تأثير زيت ناتكوم ومستخلصات أولق اداهوتا فازيكا على نسبة فقس بيض دودة ورق القطن تحت الظروف المعملية
}

\author{
أمانى سامى الحفنى ، حسام أحمد صالح شنوده سيد يعقوب \\ معهز بحوث وقاية النباتات - مركز البحوث الزراعبة - دقى - جيزة
}

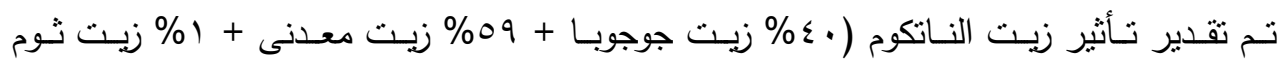

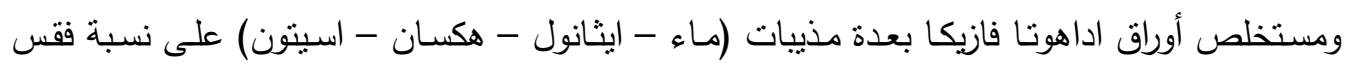

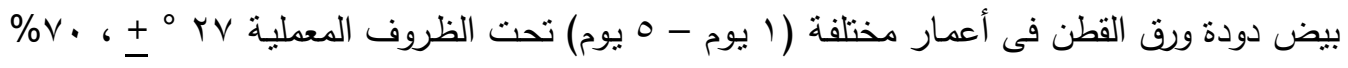
رطوبة نسبية.

حيث حقق زيت الناتكوم بمختلف تركيزاته اعلى تأثنير على البيض بأعماره المختلفة لاسيما ان

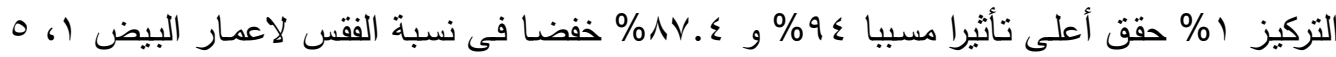

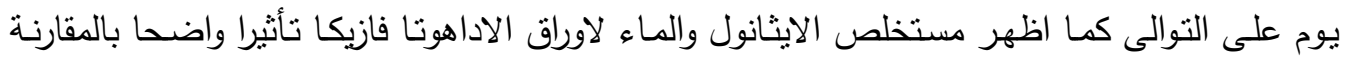
بباقى المذيبات المستخدمة (الاسينون والهكسان). وبصفة عامة فان المستخلصات النباتية كان لها تأثنير أعلى على البيض عمر (ه أيام). 